\title{
Soil temperature and intermittent frost modulate the rate of recovery of photosynthesis in Scots pine under simulated spring conditions
}

\author{
Ingo Ensminger ${ }^{1,3, *}$, Lilian Schmidt ${ }^{1, *}$ and Jon Lloyd ${ }^{2}$ \\ ${ }^{1}$ Max-Planck-Institut für Biogeochemie, Hans-Knöll-Straße 10, 07745 Jena, Germany; ${ }^{2}$ Earth and Biosphere Institute, School of Geography, University of \\ Leeds, Leeds LS2 9JT, UK; ${ }^{3}$ Present address: Max-Planck-Institut für Molekulare Pflanzenphysiologie, Am Mühlenberg 1, 14476 Golm, Germany and Institut \\ für Forstbotanik und Baumphysiologie, Universität Freiburg, 79110 Freiburg, Germany.
}

Author for correspondence: Ingo Ensminger

Tel: +49 (0) 7612038309

Fax: +49(0) 7612038302

Email: ingo.ensminger@ctp.uni-freiburg.de

Received: 26 June 2007

Accepted: 23 August 2007

\section{Summary}

- An earlier onset of photosynthesis in spring for boreal forest trees is predicted as the climate warms, yet the importance of soil vs air temperatures for spring recovery remains to be determined. Effects of various soil- and air-temperature conditions on spring recovery of photosynthesis in Scots pine (Pinus sy/vestris) seedlings were assessed under controlled environmental conditions.

- Using winter-acclimated seedlings, photosynthetic responses were followed after transfer to different simulated spring conditions.

- Recovery rates for photosynthetic electron transport and net $\mathrm{CO}_{2}$ uptake were slower in plants from cold or frozen soil compared with controls. In addition, a greater fraction of light absorbed was not used photochemically, but was dissipated thermally via xanthophyll cycle pigments. Intermittent frost events decreased photosynthetic capacity and increased thermal energy dissipation. Within a few days after frost events, photosynthetic capacity recovered to prefrost levels. After $18 \mathrm{~d}$ under spring conditions, no difference in the optimum quantum yield of photosynthesis was observed between seedlings that had been exposed to intermittent frost and control plants.

- These results show that, if air temperatures remain favourable and spells of subfreezing air temperatures are only of short duration, intermittent frost events delay but do not severely inhibit photosynthetic recovery in evergreen conifers during spring. Cold and/or frozen soils exert much stronger inhibitory effects on the recovery process, but they do not totally inhibit it.

\begin{abstract}
Abbreviations
$\Delta F / F_{\mathrm{m}}{ }^{\prime}$ ', effective quantum yield of photosynthesis in the light; $1-q P$, excitation pressure as a measure of the relative reduction state of PSII; $A$, antheraxanthin; $A_{\text {sat }}$ $\mathrm{CO}_{2}$ uptake at $1000 \mu \mathrm{mol}$ photons $\mathrm{m}^{-2} \mathrm{~s}^{-1}$; Car, carotenoid pigments; Chl, chlorophyll; $C_{\mathrm{i}} / C_{\mathrm{a}}$, ratio of internal to atmospheric $\mathrm{CO}_{2}$ concentration; DEPS, de-epoxidation state of xanthophyll cycle pigments; D1, reaction centre protein of PSII; $F_{\mathrm{m}}{ }^{\prime}$ maximal fluorescence at closed PSII centres under actinic light; $F_{0}{ }^{\prime}$, minimal fluorescence at open PSII centres immediately after illumination; $F_{\mathrm{v}}{ }^{\prime}$ variable fluorescence under actinic light; $F_{\mathrm{m}^{\prime}}$ maximal fluorescence at closed PSII centres; $F_{\mathrm{o}^{\prime}}$ instantaneous (dark) fluorescence at open PSII reaction centres; $F_{\mathrm{v}}$, variable fluorescence; $F_{\mathrm{v}} / F_{\mathrm{m}}{ }^{\prime}$, optimum quantum yield of photosynthesis in dark-acclimated needles; $g_{s}$, stomatal conductance; PPFD, photosynthetic photon flux density; PsbS, small protein subunit
\end{abstract}

*These authors contributed equally to this work. 
of PSII involved in nonphotochemical quenching; PSI, PSII, photosystems I and II, respectively; RbcL, large subunit of Rubisco; $r E T R$, relative rate of electron transport; $V$, violaxanthin; $V c_{\max }$, maximum carboxylation rate of Rubisco; $Z$, zeaxanthin

Key words: climate change, cold stress, photochemical and nonphotochemical quenching, Scots pine (Pinus sy/vestris), xanthophyll cycle.

New Phytologist (2008) 177: 428-442

(C) The Authors (2007). Journal compilation @ New Phytologist (2007)

doi: 10.1111/j.1469-8137.2007.02273.x

\section{Introduction}

Warmer air temperatures are hypothesized to cause an earlier onset of photosynthetic activity in northern hemisphere forests in spring (Suni et al., 2003). Nevertheless, factors determining the timing and rate of the spring photosynthetic recovery in these conifers are not well understood in terms of both underlying physiology and associated environmental triggers (Suni et al., 2003; Ensminger et al., 2004; Slot et al., 2005). A mechanistic explanation of the seasonal phenology of photosynthesis in evergreen conifers can, however, be derived from the concept of photostasis (Huner et al., 1998; Öquist et al., 2001). Absorption of light under low-temperature conditions by green needles can cause photooxidative damage of the photosynthetic apparatus, created by an imbalance between the photochemical generation of electrons and their diminished utilization caused by decreasing sink capacity: the downregulation of metabolism and growth during autumn and winter. This is why evergreen plants need to acclimatize photosynthesis via a suite of photoprotective mechanisms (Öquist \& Huner, 2003). These include, for example, accumulation of zeaxanthin in the antennae to facilitate thermal dissipation of excessive light energy (for recent reviews see Niyogi, 1999; Demmig-Adams \& Adams, 2006; Ensminger et al., 2006).

Such protective mechanisms allow evergreen trees to retain much of their photosynthetic apparatus during the winter period, despite being exposed to adverse environmental conditions. Recent studies have demonstrated that winter retention of key proteins of photosynthesis and carbon metabolism, such as thylakoid membrane-bound lightharvesting complexes, ATPase or Rubisco, as well as some of the chlorophyll, allows a rapid recovery of $\mathrm{CO}_{2}$ assimilation once more favourable conditions occur in spring (Adams et al., 2004; Ensminger et al., 2004; Warren \& Adams, 2004; Zarter et al., 2006).

A major trigger for the recovery process in spring is an increase in air temperature (Leinonen et al., 1997; Suni et al., 2003; Sevanto et al., 2006) to above $0^{\circ} \mathrm{C}$, favouring the operation of biochemical reactions including repair and reorganization of the photosynthetic apparatus (Ensminger et al., 2004, 2006). At this time, soluble carbohydrates that have accumulated during the previous autumn and that have acted as cryoprotective agents during winter are consumed in associated respiratory processes (Mandre et al., 2002).

Recently, we suggested that the physiological state of the chloroplast is the driving factor for the onset of photosynthesis in spring in boreal Scots pine, which is determined by the excitation pressure on PSII and PSI as a result of the light and temperature regime imposed by the environment (Ensminger et al., 2004; Sveshnikov et al., 2006). This suggests a likely earlier onset of spring photosynthesis as a consequence of climate change. However, the 'de-acclimation' processes on the needle level must be orchestrated to some extent with the overall recovery of metabolic activity and growth. It might therefore be dependent on prevailing soil temperatures, as low soil-temperature conditions during spring are considered to restrict water uptake and root activity (Lopushinsky \& Kaufmann, 1984; Bergh \& Linder, 1999; Jarvis \& Linder, 2000; Strand et al., 2002; Suni et al., 2003; Repo et al., 2005). Limited water availability caused by subzero soil temperatures in combination with high light intensities may also enhance photoinhibition and thereby delay the recovery process (Repo et al., 2005). In addition, despite an earlier onset of recovery in spring, the possibility of increased intermittent frosts might constrain the overall net rate of recovery of photosynthesis, with an adverse impact on overall tree carbon balances with increased costs of repair and respiration for subsequent frost and cold temperature episodes (Ensminger et al., 2004).

Here we hypothesize that an interaction of air and soil temperatures modulates the recovery of photosynthesis of evergreen conifers in spring, reflected largely through changes in PSII activity, pigment composition and photosynthetic gas exchange, as well as in the expression of key proteins of photosynthesis. We used winter-acclimated seedlings of Pinus sylvestris in a factorial design with four different spring recovery treatments in controlled growth environments: (i) to distinguish the importance of air temperature vs soil temperature effects on the spring recovery of the photosynthetic process; (ii) to establish the extent to which intermittent frost affects the recovery process; and (iii) to conclude how soil temperature regime and intermittent frost can affect the photosynthetic carbon uptake of evergreen conifer trees during the spring recovery phase. 
Table 1 Overview of growth conditions within five climate-controlled growth chambers

\begin{tabular}{lll}
\hline Experimental treatment & $\begin{array}{l}\text { Air temperature } \\
\left({ }^{\circ} \mathrm{C} \text {, day/night }\right)\end{array}$ & $\begin{array}{l}\text { Soil temperature } \\
\left({ }^{\circ} \mathrm{C} \text {, day/night }\right)\end{array}$ \\
\hline Winter & $-3 /-5$ & $-3 /-5$ \\
$15 / 15$ & $15 / 10$ & $15 / 10$ \\
$15 /+1$ & $15 / 10$ & $+1 /+1$ \\
$15 /-2$ & $15 / 10$ & $-2 /-2$ \\
$15 F / 15$ & $15 / 10$ & $15 / 10$ \\
$15 F / 15$ during frost & $-2 /-2$ & $-2 /-2$ \\
$\quad$ (intermittent frost on days & & \\
5-6 and 11-14) & & \\
\hline
\end{tabular}

To assess the effect of soil temperature, seedlings exposed to $15 / 15$, $15 /+1$ and 15/-2 conditions were allowed to grow in two separate growth chambers. To assess the effect of intermittent frost, seedlings exposed to $15 \mathrm{~F} / 15$ were allowed to grow in a second set of two separate growth chambers.

\section{Materials and Methods}

\section{Experimental setup}

Seeds derived from Pinus sylvestris L. trees from Hyytiällä, southern Finland (for a detailed site description see Suni et al., 2003) were placed in perlite substrate in June 2003. Plants were watered regularly and fertilized using Ingestad's solution (Ingestad, 1979). After $4 \mathrm{wk}$, seedlings were picked and kept in a glasshouse at the Max Planck Institute for Biogeochemistry in Jena, Germany. Growth conditions were $25^{\circ} / 15^{\circ} \mathrm{C}$ day/ night, $70 / 60 \%$ RH, 17 h photoperiod. In December 2003, plants were transferred to pots (22 cm deep, $18 \mathrm{~cm}$ diameter) containing a forest soil/perlite substrate, and were exposed to simulated autumn conditions $\left(15 / 5^{\circ} \mathrm{C}\right.$ day/night, $70 / 60 \%$ $\mathrm{RH}, 8 \mathrm{~h}$ photoperiod). After 3 months, fully acclimated (coldhardened) seedlings were transferred to a growth chamber (York $\mathrm{GmbH}$, Mannheim, Germany) and exposed first to mild winter conditions $\left(-2 /-5^{\circ} \mathrm{C}\right.$ day/night, photosynthetic photon flux density, PPFD $=100 \mu \mathrm{mol} \mathrm{m}^{-2} \mathrm{~s}^{-1}$, provided by metal halide lamps (EYE MT 400 DL, Iwasaki Electric Co., Tokyo, Japan) and $8 \mathrm{~h}$ photoperiod for $10 \mathrm{~d}$ ), followed by late winter conditions with a decreased temperature during the day, increased PPFD $\left(-3 /-5^{\circ} \mathrm{C}\right.$ day/night and $300 \mu \mathrm{mol} \mathrm{m} \mathrm{m}^{-2} \mathrm{~s}^{-1}$ provided by metal halide lamps, EYE MT $150 \mathrm{D}$ ) and a photoperiod of $8 \mathrm{~h}$ for $10 \mathrm{~d}$. Acclimation of seedlings to the moderate winter temperature and light conditions in the growth chamber, as compared with winter growth conditions in the field, was assessed using a portable fluorometer (PAM-2000, Heinz Walz $\mathrm{GmbH}$, Effeltrich, Germany). We assumed winter acclimation and sustained downregulation of photosynthesis when predawn values of the optimum quantum yield of PSII $\left(F_{\mathrm{v}} / F_{\mathrm{m}}\right)$ were $<0.45$ (Horton et al., 1996). Winter-acclimated seedlings were then transferred to spring ambient air temperature conditions in growth chambers (simulated by $15 / 10^{\circ} \mathrm{C}$ day/ night, PPFD $=300 \mu \mathrm{mol} \mathrm{m} \mathrm{m}^{-2} \mathrm{~s}^{-1}, 14 \mathrm{~h}$ photoperiod) for a total of $18 \mathrm{~d}$, while a subset of seedlings remained under winter conditions.

Four different spring treatments were used (Table 1), and each treatment was repeated twice, each with 18 plants. Two separate growth chambers ( 1 and 2$)$ were used to assess the effect of soil temperature on the spring recovery process in seedlings exposed to warm air and warm soil temperatures (termed 15/15), warm air and cold but nonfrozen soil (soil temperature at $+1^{\circ} \mathrm{C}$, termed $15 /+1$ ) and warm air and frozen soil (soil temperature at $-2^{\circ} \mathrm{C}$, termed $15 /-2$ ). Pots containing seedlings were placed in large plastic trays filled with sand, which completely surrounded the root zone of the seedlings within the pots. In the $15 /+1$ and $15 /-2$ treatments, cooling coils within the sand surrounded the pots. Soil temperature was maintained at 1 and $-2^{\circ} \mathrm{C}$, respectively, by continuous flow of cooling medium using an external thermostat (Peter Huber Kältebaumaschinen GmbH, Offenburg, Germany). Treatment effects on these seedlings were estimated using twoway ANova (see Statistics). Two separate growth chambers (3 and 4) were used to assess the effect of intermittent frost on the spring recovery process. Pine seedlings were exposed to warm air and warm soil with intermittent frost events (sequences of 2 and $4 \mathrm{~d}$ with air temperature $-2 /-2^{\circ} \mathrm{C}$ day/night, termed $15 \mathrm{~F} / 15$. The term ' $15 \mathrm{~F} / 15$ during frost' refers to data points and measurements from samples of the $15 \mathrm{~F} / 15$ treatment during an intermittent frost). The effect of intermittent frost compared with $15 / 15$ plants growing in chambers 1 and 2 was estimated using one-way ANOva (see Statistics). Pt 100 temperature probes inserted at $15 \mathrm{~cm}$ depth within the pots were used to control the thermostat temperature in the treatments with +1 and $-2^{\circ} \mathrm{C}$ soil temperature. In addition, for each box, soil temperature was recorded using two thermocouples connected to a datalogger (CR10X with multiplexer AM16/32; Campbell Scientific Ltd., Bremen, Germany). The surface of the sand and the pots were covered with polystyrene to simulate the insulating effect of snow covering the ground. Plants were watered regularly, except those from the 15/-2 treatment with frozen soil.

\section{Photosynthetic gas exchange}

Leaf gas-exchange measurements started not earlier than $2 \mathrm{~h}$ after the lights were turned on in the growth chambers. For gasexchange measurements with a Li-6400 (Li-Cor, Lincoln, NE, USA), $c$. eight needles that remained attached to the seedlings were placed into the cuvette to form a flat area. Light-saturated net assimilation $\left(A_{\text {sat }}\right)$ and stomatal conductance $\left(g_{s}\right)$ were measured within the cuvette routinely at a $\mathrm{CO}_{2}$ concentration $\left(C_{\mathrm{a}}\right)$ of $400 \mu \mathrm{mol} \mathrm{mol}^{-1}$ and at a saturating PPFD of 1000 $\mu \mathrm{mol} \mathrm{m}{ }^{-2} \mathrm{~s}^{-1}$ once steady-state photosynthesis was achieved (usually after approx. $7 \mathrm{~min}$ ) according to Farquhar \& von Caemmerer (1982). The cuvette temperature was always set to the seedling growth temperature. The airflow was controlled by 
the Li-6400 system to keep humidity within the chamber constant during measurements. During measurements under spring conditions $\left(15^{\circ} \mathrm{C}\right)$, VPD was typically in the range $0.7-$ $1.2 \mathrm{kPa}$; under winter conditions and during frost in $15 \mathrm{~F} / 15$, VPD was in the range $0.2-0.3 \mathrm{kPa}$.

In addition to routine measurements of $A_{\text {sat }}, \mathrm{CO}_{2}$-response curves $\left(A / C_{\mathrm{i}}\right)$ were obtained during frost (day 14$)$ in the $15 \mathrm{~F} /$ 15 treatment and at the end of the experiment in all treatments (day 18). $A / C_{\mathrm{i}}$ curves were measured using $\mathrm{CO}_{2}$ concentrations of $800,600,400,200,50$ and $0 \mu \mathrm{mol}$ at a PPFD of $1000 \mu \mathrm{mol} \mathrm{m}{ }^{-2} \mathrm{~s}^{-1}$. Photosynthesis parameters were calculated according to Farquhar \& von Caemmerer (1982) to estimate the maximum carboxylation velocity of Rubisco $\left(V c_{\max }\right)$, and $C_{\mathrm{i}} / C_{\mathrm{a}}$ using the $A / C_{\mathrm{i}}$-response data. These parameters were obtained by least-squares fitting of the observed data points using the PHOTOSYN ASsistant software package (Dundee Scientific, Dundee, UK). All responses were calculated with model parameters set to growth temperature.

During measurements of gas exchange, needles remained attached to the seedlings and were harvested subsequently and scanned to determine the light exposed (upper) surface area using the WINSEEDLE software package (Regent Instruments Inc., Québec City, QC, Canada). The rate of photosynthetic gas exchange was then expressed per surface area exposed to the light.

\section{Chlorophyll fluorescence}

Similarly to gas exchange, determinations of chlorophyll fluorescence started after at least $2 \mathrm{~h}$ photosynthesis in the growth chambers. Chlorophyll fluorescence of attached needles was measured using a PAM-2000. Light-acclimated needles were first exposed to actinic light $\left(500 \mu \mathrm{mol}\right.$ photons $\left.\mathrm{m}^{-2} \mathrm{~s}^{-1}\right)$ for $3 \mathrm{~min}$, followed by a pulse of completely saturating light (6000 $\mu \mathrm{mol}$ photons $\left.\mathrm{m}^{-2} \mathrm{~s}^{-1}, 600 \mathrm{~ms}\right)$. Immediately after obtaining the maximal fluorescence of the light-acclimated sample $\left(F_{\mathrm{m}}{ }^{\prime}\right)$, the light was shut off and the needles exposed to weak far-red light to measure the minimal fluorescence of the lightacclimated needles $\left(F_{\mathrm{o}}{ }^{\prime}\right)$. Following this sequence, the transient fluorescence $\left(F_{\mathrm{t}}\right)$ was recorded in the light once steady-state fluorescence was attained. Needles were then kept in darkness for $2 \mathrm{~h}$ before maximal and minimal fluorescence of the darkacclimated sample $\left(F_{\mathrm{o}}\right.$ and $\left.F_{\mathrm{m}}\right)$ were assessed.

The ratio of variable to maximal fluorescence, reflecting the optimal quantum efficiency of PSII in the dark, was calculated as $F_{\mathrm{v}} / F_{\mathrm{m}}=\left(F_{\mathrm{m}}-F_{\mathrm{o}}\right) / F_{\mathrm{m}}$, and the effective quantum efficiency of PSII in the light was calculated as $\Delta F / F_{\mathrm{m}}{ }^{\prime}=\left(F_{\mathrm{m}}{ }^{\prime}-F_{\mathrm{t}}\right) / F_{\mathrm{m}}{ }^{\prime}$. The relative rates of electron transport from PSII to PSI (rETR) were calculated as $\Delta F / F_{\mathrm{m}}{ }^{\prime} \times \mathrm{PPFD} \times 0.5$ according to Genty et al. (1989).

The excitation pressure on PSII describing the fraction of closed reaction centres caused by the reduction state of the primary electron acceptor $Q_{\mathrm{A}}$ in the light-adapted state was expressed as $1-q P=\left(F_{\mathrm{t}}-F_{\mathrm{o}}{ }^{\prime}\right) /\left(F_{\mathrm{m}}{ }^{\prime}-F_{\mathrm{o}}{ }^{\prime}\right)$ according to Björkmann \& Demmig-Adams (1995).

The partitioning of the absorbed light energy was calculated according to Demmig-Adams et al. (1996). The fraction of the absorbed light used in photochemistry was calculated as $P=F_{\mathrm{v}}{ }^{\prime} / F_{\mathrm{m}}{ }^{\prime} \times q P$ with $q P$ representing the fraction of open reaction centres and being expressed as $\left(F_{\mathrm{m}}{ }^{\prime}-F_{\mathrm{m}}\right) /\left(F_{\mathrm{m}}{ }^{\prime}-F_{\mathrm{o}}{ }^{\prime}\right)$. Thermal dissipation was calculated as $D=1-F_{\mathrm{v}}{ }^{\prime} / F_{\mathrm{m}}{ }^{\prime}$. $D$ represents regulatory changes in the efficiency with which excitation energy is delivered to open PSII centres (Demmig-Adams et al., 1996), thus giving an estimate of nonphotochemical quenching. Excess energy, reflecting the fraction of absorbed light neither used photochemically nor dissipated via regulated thermal processes and potentially damaging for PSII, was estimated as $E=F_{\mathrm{v}}{ }^{\prime} / F_{\mathrm{m}}{ }^{\prime} \times(1-q P)$ (Kato et al., 2003; Kornyeyev et al., 2003).

\section{Needle water potential}

The water potential of individual needles was determined using a pressure bomb (Scholander et al., 1964). Measurements were carried out in the morning before the lights were switched on in the growth chambers, as described by Lloyd \& Howie (1989).

\section{Sampling for determination of photosynthetic pigments and thylakoid proteins}

Needles were sampled for analysis of photosynthetic pigments (chlorophylls and carotenoids) on day 14 in the $15 \mathrm{~F} / 15$ treatment (during intermittent frost) and from all treatments (including intermittent frost) on day 18 following transfer to spring conditions for three randomly chosen plants of each replicate and from seven plants maintained under winter conditions. Sampling of needles started not earlier than $2 \mathrm{~h}$ after the lights were turned on in the growth chambers. Immediately after sampling, needles were frozen in liquid nitrogen and subsequently stored at $-80^{\circ} \mathrm{C}$ until further analysis.

\section{Photosynthetic pigments}

Needles were ground to a fine powder in liquid $\mathrm{N}$ and subsequently freeze-dried. Extraction of photosynthetic pigments was carried out according to Ensminger et al. (2004) using 99.9\% acetone buffered with $\mathrm{NaHCO}_{3}$ under low-light conditions at $4^{\circ} \mathrm{C}$. Extracts were used to determine photosynthetic pigments by HPLC with a reversedphase $\mathrm{C} 18$ column (Supelco, Bellefonte, PA, USA) according to Ensminger et al. (2001).

\section{Nonstructural carbohydrates}

Whole seedlings from spring and winter conditions were sampled on the last day of the experiment and separated into 
roots, shoots and needles, dried at $75^{\circ} \mathrm{C}$ for $72 \mathrm{~h}$ (modified from Rose et al., 1991), and stored in a desiccator until further analysis.

Dried plant material $(50 \mathrm{mg})$ was homogenized in a FastPrep FP120 instrument (Thermo Savant, Holbrook, NY, USA) during four runs each of $35 \mathrm{~s}$ at 4.5 speed using steel beads ( $2 \mathrm{~mm}$ diameter, ASK Kugellagerfabrik Artur Seyfert GmbH, Korntal-Münchingen, Germany). Soluble sugars and starch were extracted from the homogenized plant material according to Ögren (1997) and determined spectrophotometrically by the anthrone method (Jermyn, 1975). Standard curves were derived using $\delta$-D-(+)-glucose monohydrate in $80 \%$ ethanol and soluble starch in $30 \%$ perchloric acid.

\section{Proteins of photosynthesis}

To estimate the abundance of the photosynthetic proteins $\mathrm{D} 1, \mathrm{PsbS}$ and RbcL, total protein was extracted according to Ensminger et al. (2004) in a buffer containing $0.12 \mathrm{M}$ Tris- $\mathrm{HCl}$ ( $\mathrm{pH}$ 6.8), 4\% SDS and 30\% sucrose by sonication (three cycles each of $20 \mathrm{~s}$ on ice) and following solubilization at $75^{\circ} \mathrm{C}$ for $5 \mathrm{~min}$. For SDS-PAGE, $0.04 \mathrm{~m}$ DDT was added. Twenty $\mu \mathrm{g}$ protein was loaded per lane on 10\% Bis-Tris gels (NuPage, Invitrogen, Karlsruhe, Germany). Following electrophoretic protein separation using a MES/SDS running buffer, proteins were transferred to a PVDF membrane $(0.2 \mu \mathrm{m}$ pore size; BioRad, München, Germany) and probed with specific antibodies against PsbS, RbcL and D1 (Agrisera, Vännäs, Sweden). Proteins were detected on the membrane using chemiluminescence (ECL detection kit, Amersham, Freiburg, Germany), and the optical density of each band was quantified using the sCION software package (Scion Corp., Frederick, MA, USA).

\section{Statistics}

spss 14.0 (Chicago, IL, USA) was used for most statistical analysis. Normal distribution of the data was tested using the one-sample Kolmogorov-Smirnoff test. The effect of soil temperature on 15/15, 15/+1 and 15/-2 seedlings was analysed by two-way ANOva using 'treatment' and 'chamber' as fixed factors. Chamber or the interaction of chamber $\times$ treatment never had any significant effect. To test frost effects, we first used one-way ANOva to test that there was no significant effect of chamber (chambers 3 and 4 ) on the seedlings growing under $15 \mathrm{~F} / 15$ conditions. In a second step, we compared the average values obtained per chamber and treatment $(n=2)$ of $15 / 15$ and $15 \mathrm{~F} / 15$ seedlings using one-way ANOva. Whereas for the statistical analysis $n$ varied depending on the treatment $(n=4-$ 6 for soil temperature treatments; $n=2$ for intermittent frost treatments), data shown in all figures and tables represent the average per treatment across two chambers and identical treatments \pm SD. (Line fits in Figs 1,4 come from a multilevel segmented regression analysis; Table $S 1$ in Supplementary Material.)

\section{Results}

\section{Chlorophyll fluorescence}

Effects of soil temperature and intermittent frost on the quantum yield of fluorescence $A$ temperature shift from winter to spring air temperature conditions $\left(15 / 10^{\circ} \mathrm{C}\right.$ day/ night) rapidly triggered recovery of the optimum quantum yield of photosystem II $\left(F_{\mathrm{v}} / F_{\mathrm{m}}\right)$, indicating an increase in functional PSII reaction centres (Fig. 1a,b) within $24 \mathrm{~h}$. This was also shown by a major increase in the effective quantum yield $\left(\Delta F / F_{\mathrm{m}}{ }^{\prime}\right)$ obtained from samples exposed to $500 \mu \mathrm{mol}$ photons $\mathrm{m}^{-2} \mathrm{~s}^{-1}$. This recovery occurred irrespective of the soil temperature treatment (Fig. 1a,c). Overall, the temporal pattern shows two phases in the response of $F_{\mathrm{v}} / F_{\mathrm{m}}$ and $\Delta F / F_{\mathrm{m}}{ }^{\prime}$. A first rapid phase occurred within $24 \mathrm{~h}$ after the transfer to spring conditions, accounting for $65 \%$ of the total recovery (days $0-1$; Fig. 1a,c). This is followed by a second, much slower phase occurring for $c .10$ more days thereafter (Table S1). Although after $18 \mathrm{~d}$ exposure to spring conditions all treatments exhibited similar patterns of $F_{\mathrm{v}} / F_{\mathrm{m}}$ (Fig. 2a,b), there were significant differences in $\Delta F / F_{\mathrm{m}}{ }^{\prime}$ (Fig. $1 \mathrm{c}$,d; Table $\left.S 1 ; P<0.05\right)$ and in the relative rate of photosynthetic electron transport (rETR, Table 2). Although rETR was lower for seedlings exposed to 15/-2 treatment than for seedlings from $15 / 15$ or $15 /+1$, the effect of soil temperature was not significant.

There was no significant effect of intermittent frost when comparing $15 / 15$ and $15 \mathrm{~F} / 15$ plants at the end of the experiment (Table 2), and significant decreases in $F_{\mathrm{v}} / F_{\mathrm{m}}$, $\Delta F / F_{\mathrm{m}}{ }^{\prime}$ (Fig. 1) and rETR only during frost events $(P<0.05$; Table 2). On the completion of intermittent frost periods, all photosynthetic parameters studied returned rapidly within $2 \mathrm{~d}$ to prefrost levels.

Increased efficiency of photochemical energy conversion was accompanied by a decrease in the excitation pressure on PSII ( $1-q P$; Table 2), and the de-epoxidation status (DEPS) of the photoprotective xanthophyll cycle pigments for all spring treatments (Fig. 1e,f). The relaxation of DEPS caused by conversion of the de-epoxidized xanthophylls zeaxanthin and antheraxanthin into the epoxidized violaxanthin, showing similar multiphasic temporal patterns as for $F_{\mathrm{v}} / F_{\mathrm{m}}$ and $\Delta F / F_{\mathrm{m}}{ }^{\prime}$. At the end of the experiment, $1-q P$ and DEPS were highest in $15 /+1$ and $15 /-2$ seedlings, with soil temperature effects being significant $(P<0.05)$. For both $\triangle F / F_{\mathrm{m}}{ }^{\prime}$ and DEPS, these differences at the end of the experiment were caused by vastly different rates of recovery from days 1-11, after which no significant differences were observed, irrespective of soil temperature treatment (Table S1).

Levels of $1-q P$ and DEPS were exceeded only during intermittent frost in $15 \mathrm{~F} / 15$ seedlings, with the effect of intermittent frost also being significant for $1-q P$ (Table 2). 
New

Phytologist

(a)

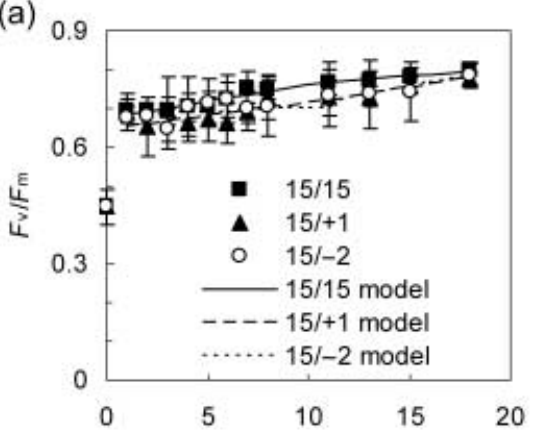

(c)

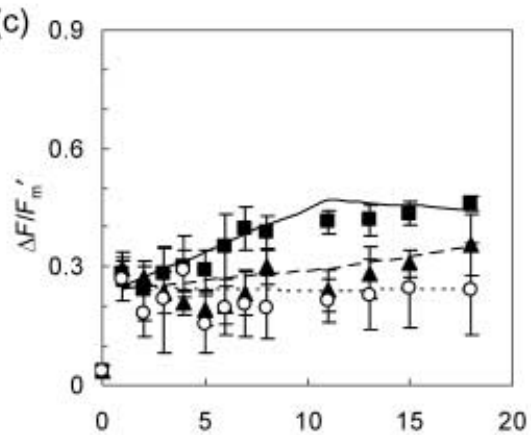

(e)

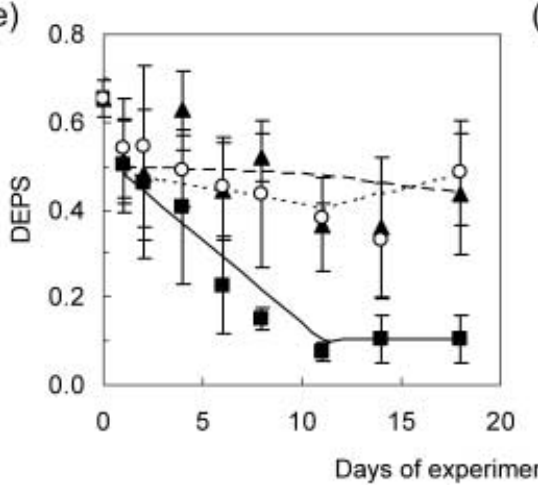

(b)

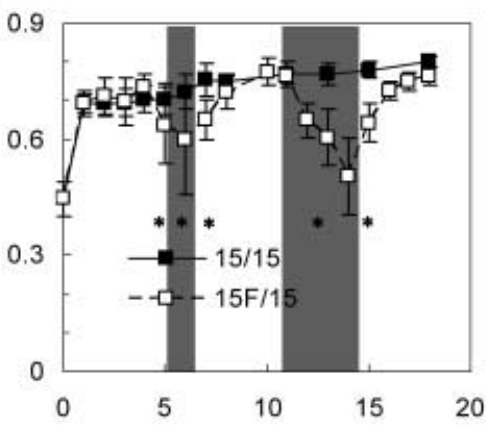

(d) 0

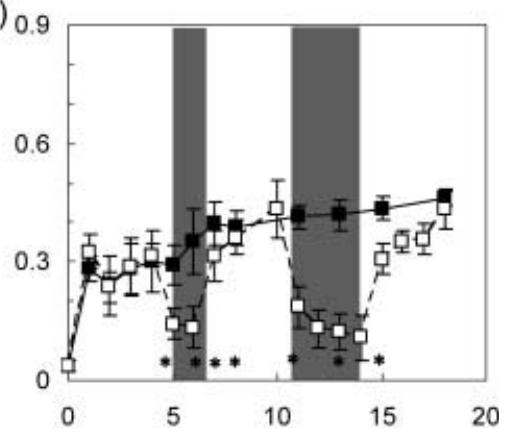

(f)

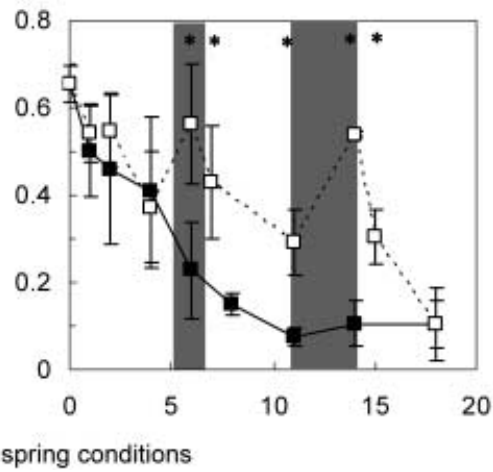

Effect of soil temperature and intermittent frost on energy partitioning in seedlings In winter-acclimated seedlings, 78\% of the light energy absorbed by the antennae was dissipated thermally, with only $4 \%$ used to drive photochemical processes. The remaining $18 \%$ of the energy absorbed was in excess and was not quenched photochemically or via thermal dissipation (Fig. 2). After $18 \mathrm{~d}$ exposure to continuous $15^{\circ} \mathrm{C}$ air temperature, the fraction of photochemically converted energy had been increased significantly and the level of thermally dissipated energy had been decreased significantly in 15/15 seedlings (Fig. 2). Soil temperature was affecting the pattern of photosynthetic energy partitioning, with a significant negative effect on the fraction of energy being used for photochemical processes after $18 \mathrm{~d}(46 \%$ in $15 / 15$ vs only $24 \%$ for $15 /-2)$, and with plants from the 15/-2 treatment dissipating the largest fraction of energy via heat (56\%). Nevertheless, soil temperature did not have any effect on the fraction of excess energy that was neither used for photochemistry nor dissipated thermally (Fig. 2).
For $15 \mathrm{~F} / 15$ plants, the pattern was reversibly affected during intermittent frost periods with significant effects on the thermal $(P<0.01)$ and photochemical $(P<0.01)$ quenching. However, at the end of the experiment we did not discern any differences between 15/15 and 15F/15 seedlings (Fig. 2).

\section{Differences in proteins of photosynthesis}

Expression of the D1 reaction centre protein of PSII was lowest under winter conditions (Fig. 3a), with the highest levels of expression after $18 \mathrm{~d}$ recovery occurring for the $15 / 15$ treatment $(P<0.05)$. Values for the $15 /+1$ and $15 \mathrm{~F} / 15$ treatments were intermediate. Nevertheless, soil temperature effects were not significant. Likewise, intermittent frost also caused no significant differences in D1 levels.

PsbS, a transthylakoid membrane protein involved in flexible nonphotochemical quenching, showed highest abundances in the $15 \mathrm{~F} / 15$ and $15 /+1$, and slightly lower abundances for the 


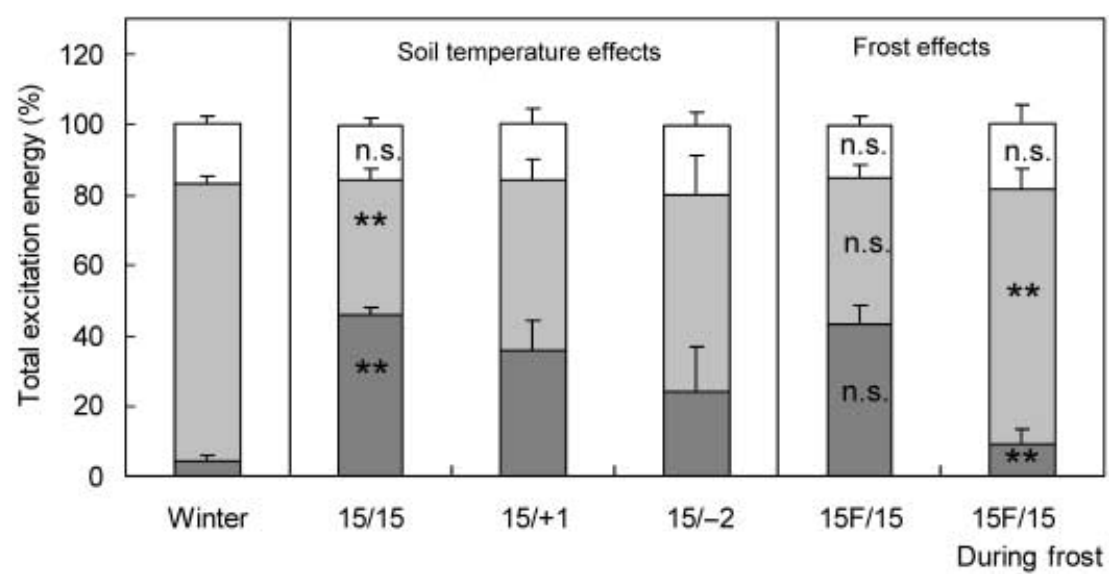

Fig. 2 Effect of soil temperature and intermittent frost on energy partitioning in photosystem II (PSII) in Scots pine (Pinus sy/vestris) needles under various experimental conditions. Dark grey bars, fraction of light energy absorbed by PSII antenna that is used for photochemical charge separation; light grey bars, thermally dissipated energy fraction; white bars, excess energy that does not go to either P or D. Each data point is the average obtained from needles of $n=6( \pm S D)$ seedlings per treatment. Two-way ANOVA indicates statistically significant differences caused by soil temperature between $15 / 15,15 /+1$ and 15/-2; one-way ANOVA indicates statistically significant differences caused by intermittent frost between $15 / 15$ and $15 \mathrm{~F} / 15$ or $15 \mathrm{~F} / 15$ and $15 \mathrm{~F} / 15$ during frost. ${ }^{*}, P=0.05 ;{ }^{*}, P=0.01$; ns, not significant. See Table 1 for treatment abbreviations and detailed description of treatments.

15/15 treatment. Higher levels of PsbS indicate an increased capacity for a flexible component of nonphotochemical quenching; statistical analysis revealed a significant effect of soil temperature on the expression levels of PsbS for 15/15, 15/+1 and 15/-2 seedlings, but no effect of intermittent frost between 15F/15 and 15/15 (Fig. 3b). By contrast, the level of the large subunit of Rubisco, RbcL, remained rather unchanged, with no significant soil temperature or intermittent frost effects (Fig. 3c).

\section{Recovery of net $\mathrm{CO}_{2}$ assimilation}

Net $\mathrm{CO}_{2}$ assimilation under saturating light $\left(A_{\text {sat }}\right)$ was almost completely suppressed under winter conditions (day 0 in Fig. 4) and showed a different pattern of recovery from that observed for the fluorescence parameters and DEPS: specifically, no rapid recovery was observed within the first $24 \mathrm{~h}$. Rather, $A_{\text {sat }}$ increased in a simple linear manner over the first $11 \mathrm{~d}$, with recovery rates for the 15/+1 and 15/-2 seedlings both being significantly slower than for $15 / 15$ seedlings during this period $(P<0.05$; Table S1). As for the fluorescence parameters and DEPS in Fig. 1, there was also no significant effect of soil temperature on rates of recovery after day 11 .

Although $A_{\text {sat }}$ was suppressed in $15 \mathrm{~F} / 15$ compared with $15 / 15$ seedlings by as much as $80 \%$ during intermittent frost events (Fig. 4b), after the 18 -d recovery period there was no significant difference in $A_{\text {sat }}$ between the two treatments.

\section{$\mathrm{CO}_{2}$ response of assimilation at the end of the} recovery process

Low or freezing soil temperatures reduced both the initial slope and maximum rates of the relationship between assimilation
$(A)$ vs internal $\mathrm{CO}_{2}$ concentration $\left(C_{\mathrm{i}}\right)$, but with the lowest overall rates being observed by $15 \mathrm{~F} / 15$ during intermittent frost periods (Fig. 5a). Fig. 5b shows the relationship between $A_{\text {sat }}$ and Rubisco activity $\left(V c_{\max }\right)$, clearly reflecting a strong correlation. The relationship between $A_{\text {sat }}$ and DEPS shows two clusters separating seedlings exposed to low soil temperature or $15 \mathrm{~F} / 15$ during intermittent frost (Fig. 5c), with higher $A_{\text {sat }}$ occurring with low DEPS values for $15 / 15$ and for $15 \mathrm{~F} / 15$ seedlings during nonfrost periods.

The sensitivity of gas exchange to intermittent frost and low soil temperatures was also reflected in differences in stomatal conductance $\left(g_{s}\right)$, with this being lowest for 15/-2 and $15 /+1$ treatments and with values being significantly affected by soil temperature $(P<0.001$; Table 2$)$. Although $g_{s}$ for $15 \mathrm{~F} /$ 15 during intermittent frost was still higher than for $15 /+1$ and $15 /-2$ seedlings at the end of the experiment, frost effects were significant in comparison with $15 / 15(P<0.01)$ and also with $15 \mathrm{~F} / 15$ values at the end of the experiment $(P<0.05$; Table 2).

Intermittent frost did not affect $C_{\mathrm{i}} / C_{\mathrm{a}}$ for the $15 \mathrm{~F} / 15$ seedlings, with values during frosts 1 and 2 being in the typical range of $0.7-0.8$ for $\mathrm{C}_{3}$ plants. Nevertheless, $C_{\mathrm{i}} / C_{\mathrm{a}}$ was significantly lower for needles of the $15 /+1$ or $15 /-2$ treatments $(P<0.05)$, and was apparently even lower than under winter conditions (Table 2).

\section{Water potential of the seedlings}

Seedlings under winter conditions, under exposure to frost, and exposed to the $15 /+1$ and $15 /-2$ treatments all had lower predawn needle water potentials $(\psi)$ than control plants, with soil temperature having a significant effect $(P<0.05)$. 
New

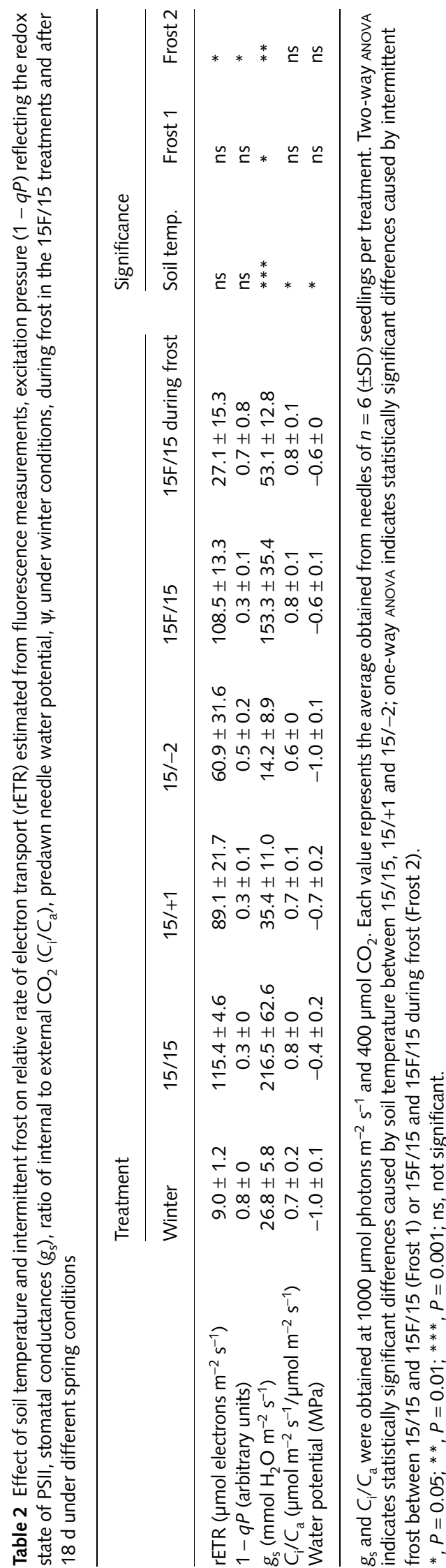

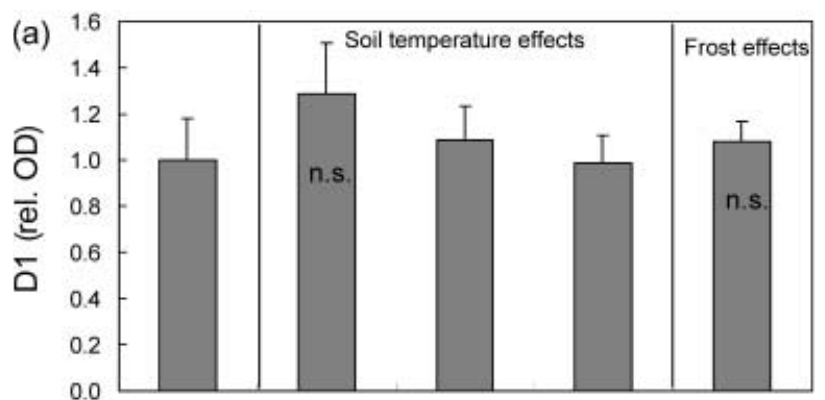
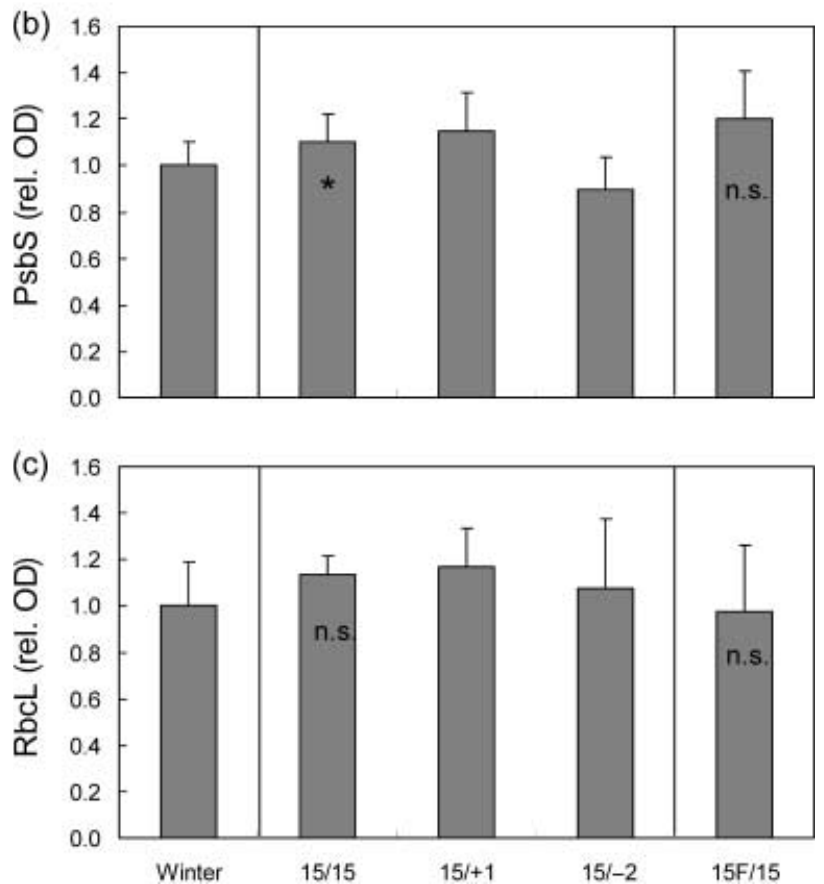

Fig. 3 Effect of soil temperature and intermittent frost on expression levels of proteins of photosynthesis in needles of Scots pine (Pinus sylvestris) at the end of the experiment. The optical density of the winter sample was arbitrarily scaled to 1 and used as a reference to calculate the expression level in the spring treatments. (a) The PSII reaction centre protein D1; (b) the small subunit of PSII involved in nonphotochemical quenching (PsbS); (c) the large subunit of Rubisco (RbcL) under winter conditions and after $18 \mathrm{~d}$ under different spring conditions. Each data point is the average obtained from needles of $n=4$ ( \pm SD) seedlings per treatment. Two-way ANOVA indicates statistically significant differences caused by soil temperature between $15 / 15,15 /+1$ and $15 /-2$; one-way ANOVA indicates statistically significant differences caused by intermittent frost between $15 / 15$ and $15 \mathrm{~F} / 15$ or $15 \mathrm{~F} / 15$ and $15 \mathrm{~F} /$ 15 during frost. ${ }^{*}, P=0.05$; ns, not significant. Refer to Table 1 for treatment abbreviations and detailed description of the treatments.

Intermittent frost exposure had no long-term effect on $\psi$, as shown by similar values for $15 \mathrm{~F} / 15$ and $15 / 15$ plants at the end of the experiment.

\section{Photosynthetic pigments}

Soil temperature and intermittent frost did not affect foliar concentrations of $\mathrm{Chl} a+b$ (dry weight basis; Table 3 ) with 
(a)

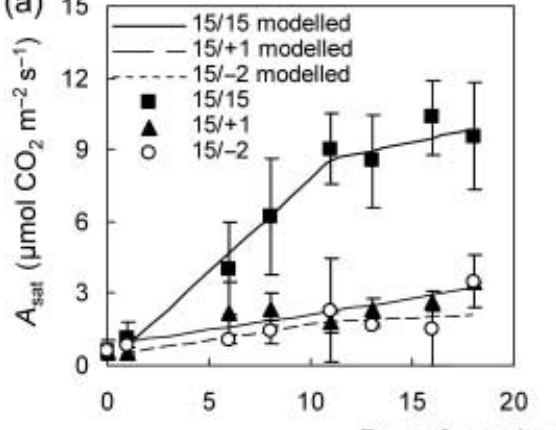

Days of experimental spring conditions (b)

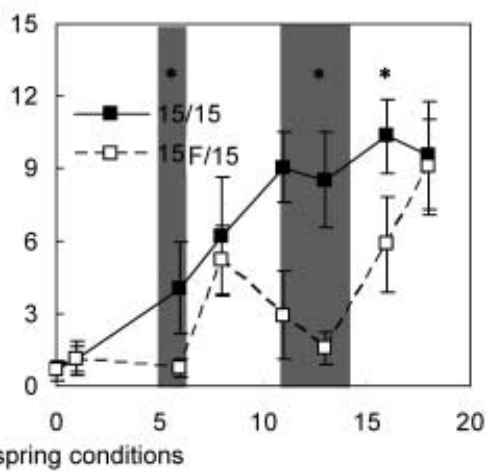

Fig. 4 Recovery of light-saturated $\mathrm{CO}_{2}$ assimilation in 1-yr-old Scots pine (Pinus sy/vestris) seedlings under different experimental spring conditions in growth chambers. Day 0 refers to winter conditions. Each data point is the average obtained from $n=4-7$ ( \pm SD) measurements. Exposure of $15 F / 15$ seedlings to periods of intermittent frost indicated by shaded background. *, $P=0.05$. See Table 1 for treatment abbreviations and detailed description of treatments.
Chl $a+b$ values after $18 \mathrm{~d}$ recovery tending to be lower for all treatments when compared with the winter-acclimated plants. Soil temperature did, however, have a significant effect on the ratio of chla to $\operatorname{chl} b(P<0.01)$ with lowest values observed in $15 /-2$. Intermittent frost promoted a relative loss of Chl $b$ in $15 \mathrm{~F} / 15$ during freezing $(P<0.05)$ and resulted in significantly lower values for $15 \mathrm{~F} / 15$ compared with $15 / 15$ at the end of the experiment $(P<0.05$; Table 3$)$.

Total carotenoid, expressed on a dry weight basis, declined after exposure to spring conditions, with neither soil temperature nor intermittent frost having any significant effect (Table 3). Likewise, the concentrations of total carotenoid to total chlorophylls did not show significant responses to soil temperature or intermittent frost, increasing only slightly in response to low soil temperature or intermittent frost. Nevertheless, the amounts of the various carotenoids varied considerably according to growth conditions. For example, the pool of lutein to chlorophyll increased in all treatments after transfer from winter conditions (Table 3). Nevertheless, none of these trends proved to be statistically significant.

Perhaps the most interesting shift occurred in the pool size of the xanthophyll cycle pigments (violaxanthin, antheraxanthin and zeaxanthin) per chlorophyll (VAZ/Chl). VAZ/Chl decreased after transfer from winter to spring air temperatures in all treatments, with the greatest decline in $15 / 15$ seedlings (Table 3). Plants exposed to low soil temperatures had lower VAZ/Chl levels than during winter stress, but still retained larger pools of xanthophylls to chlorophyll than was the case for $15 / 15$ plants $(P<0.05$; Table 3$)$. Intermittent frost did not exert any significant effect on VAZ/Chl levels, although the sequence of $4 \mathrm{~d}$ of intermittent frost temporarily reversed the decline in VAZ/Chl.

\section{Partitioning of nonstructural carbohydrates}

In general, soluble sugar concentrations in roots, shoots and needles were highest in winter-acclimated seedlings (Fig. 6). By contrast, starch concentrations were always lower in all parts of winter-acclimated seedlings. Shifting of seedlings to spring air temperatures resulted in an overall decrease in soluble sugars for all treatments. In needles, no significant soil temperature effects or effects of intermittent frost on soluble carbohydrates were discerned, and only soil temperature had significant effects on needle starch content $(P<0.01)$, with lower starch content in $15 /-2$ than in $15 / 15$ or $15 /+1$ seedlings.

For shoots, soil temperature was a significant factor affecting both soluble sugars $(P<0.01)$ and starch $(P<0.05)$, with the lowest carbohydrate content observed for the $15 / 15$ plants. Intermittent frost did not account for any difference in shoot carbohydrate levels between $15 / 15$ and $15 \mathrm{~F} / 15$ at the end of the experiment.

For roots, soil temperature had a highly significant effect on soluble carbohydrate content $(P<0.001)$, with lowest levels found in $15 / 15$. Starch levels were not affected by soil temperature. Intermittent frost did not significantly affect root soluble carbohydrate, but did cause an accumulation of starch $(P<0.01)$.

\section{Discussion}

Defence mechanisms of the photosynthetic apparatus against low temperatures during winter conditions

Low temperatures and intermittent frost are both environmental factors potentially constraining the onset of photosynthesis in northern hemisphere conifers during the winter-spring transition. Our results provide the first evidence that low soil temperatures can exert a much stronger constraining effect than intermittent frost on the spring recovery of photosynthesis. Indeed, it was remarkable that the inhibitory effect of intermittent frost on photosynthesis was negated within only a few days, once seedlings were exposed to warmer temperatures. In order to understand why short-term freezing has a much less detrimental effect on the recovery process, it is important to understand how the photosynthetic apparatus actually survives freezing winter conditions.

In our controlled experiments with relatively mild winter conditions, sustained photoinhibition represented a major component of the photosynthetic defence system. This was indicated by low $F_{\mathrm{v}} / F_{\mathrm{m}}$ (Fig. 1), similar to what is observed for field-grown plants under both mild (Adams \& Demmig-Adams, 1994; Karpinski et al., 1994; Repo et al., 2005) and harsh winter climates (Ottander et al., 1995; Ensminger et al., 2004). 
New
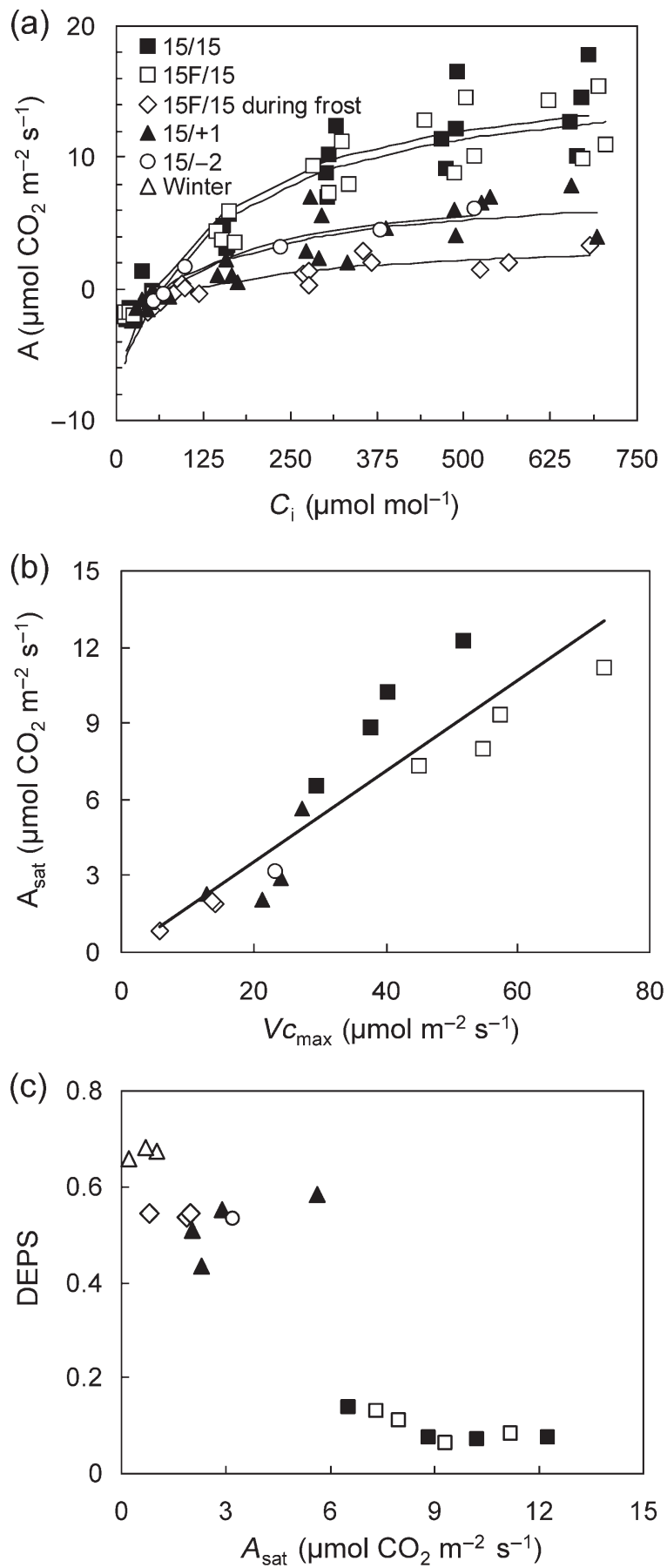

Fig. 5 (a) Response of assimilation (A) to the internal $\mathrm{CO}_{2}$ concentration $\left(C_{\mathrm{i}}\right)$; (b) relationship between $A_{\text {sat }}$ and maximum rate of Rubisco carboxylation $\left(V c_{\max }\right)\left(R^{2}=0.82, y=0.180 x+0.0 .063\right)$; (c) relationship between de-epoxidation of xanthophyll cycle pigments and $A_{\text {sat }}$ (a) Lines indicate response of $A$ to $C_{i}$ using leastsquares fitting to the observed data points (see Materials and Methods); (b,c) each data point represents a value obtained from a different plant at the end of the experiment (day 18), data points from $15 F / 15$ during frost are from day 14 . Values for $15 /-2$ were obtained from only one plant. See Table 1 for treatment

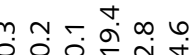

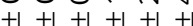
$m m-n$

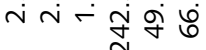

$m \sim \stackrel{\nabla}{m} \sim m$ $000 \stackrel{\sim}{\sim} \tilde{m}_{\infty}^{\infty}$

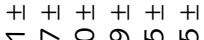

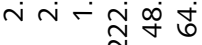

$\nabla-r \stackrel{0}{m} \ln 6$ 每

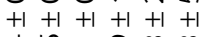

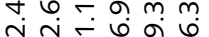
신

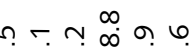
กீ:

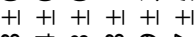

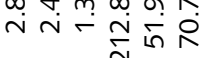

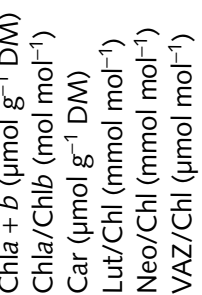

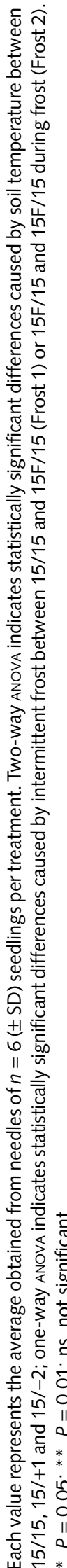


(a)

(a)

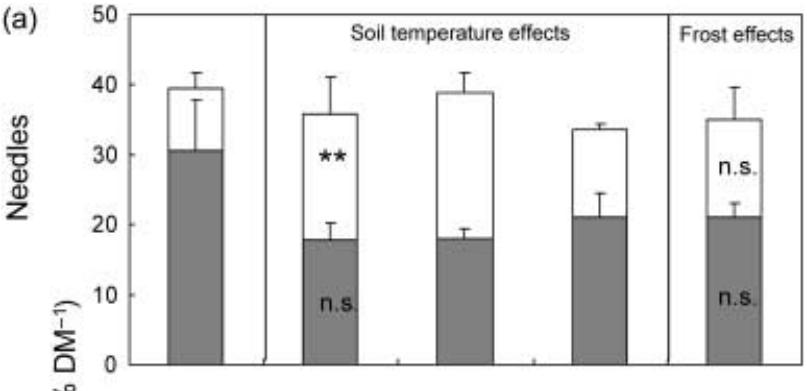

(b)

告

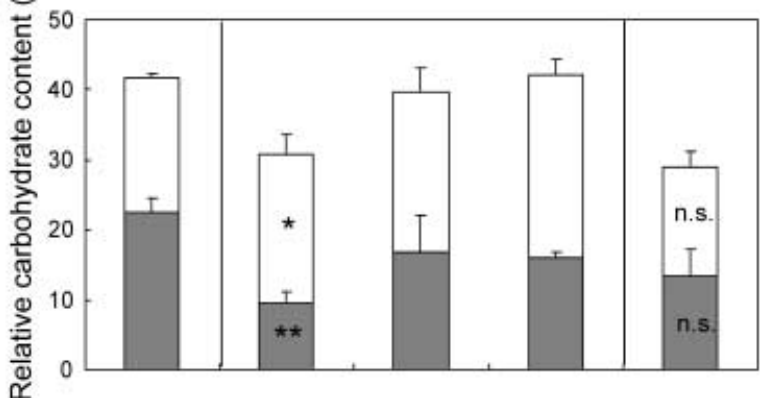

(c)

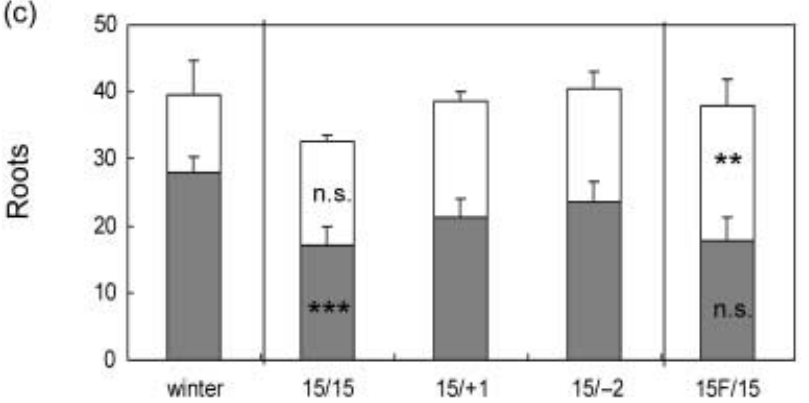

Fig. 6 Carbohydrate content in different tissues of Scots pine (Pinus sylvestris) seedlings after acclimation to either winter or experimental spring conditions. Soluble sugars (grey bars) and starch (white bars) per dry matter (DM) in needles (a); shoots (b); roots (c). Each data point is the average obtained from needles of $n=4-6$ $( \pm S D)$ seedlings per treatment. Two-way ANOVA indicates statistically significant differences caused by soil temperature between 15/15, $15 /+1$ and $15 /-2$; one-way ANOVA indicates statistically significant differences caused by intermittent frost between $15 / 15$ and $15 F / 15$ or $15 \mathrm{~F} / 15$ and $15 \mathrm{~F} / 15$ during frost. ${ }^{*}, P=0.05 ;{ }^{*}, P=0.01 ; * * *$, $P=0.001$; ns, not significant. See Table 1 for treatment abbreviations and detailed description of treatments.

Nevertheless, although net $\mathrm{CO}_{2}$ assimilation rates at saturating light were very low, they were not completely suppressed under the simulated mild winter conditions, as also reported by Hansen \& Beck (1994); Vogg et al. (1998) (Fig. 4). RbcL levels were, however, similar to those after $18 \mathrm{~d}$ of spring treatments (Fig. 3c). This indicates that photosynthetic capacity during winter is not limited by the amount of Rubisco present, but rather its function caused by downregulation of the enzyme's activity (Ensminger et al., 2006; Fig. 5b). This finding also supports the hypothesis that Rubisco may function as an important nitrogen store in conifers during the winter, which is also required to allow rapid recovery of photosynthe- sis in spring (Warren \& Adams, 2004). Although not significant, the lower expression levels of the D1 reaction centre protein of PSII during winter compared with $15 / 15$ seedlings (Fig. 3a) may have resulted from light capture exceeding energy consumption, causing over-reduction of the photosynthetic electron transport chain, thus increasing the excitation pressure on PSII $(1-q P$; Table 2$)$, this being a consequence of decreased sink capacity of the Calvin cycle under low-temperature conditions. Under such conditions, thermal dissipation of excess energy via zeaxanthin from the xanthophyll cycle helps to prevent photo-oxidative damage of thylakoid membranes (Fig. 1e,f) (Greer et al., 1991; Ottander et al., 1993; Sveshnikov et al., 2006).

Thermal dissipation of excitation energy via NPQ was high in winter plants (Fig. 2), but with the level of PsbS protein (Fig. 3b), which facilitates the flexible component of NPQ (Li et al., 2004; Stroch et al., 2004), being low at the same time. This argues towards an increase of thermal dissipation via sustained NPQ associated with PSII core rearrangements or degradation in winter-acclimated trees, as suggested by Ensminger et al. (2004); Ebbert et al. (2005).

Warm spring air temperatures rapidly release coldinduced inhibition of photosynthesis

Warm air temperatures re-established electron transport rates and light-saturated $\mathrm{CO}_{2}$ assimilation in $15 / 15$ seedlings (Table 2; Fig. 4a) (Pelkonen \& Hari, 1980; Lundmark et al., 1988; Wang \& Zwiazek, 1999), thereby helping to balance the redox state of the chloroplast and to decrease $1-q P$. The increase in $F_{\mathrm{v}} / F_{\mathrm{m}}$ values occurred within $24 \mathrm{~h}$ (Fig. 1a,b), similarly to, but much faster than, those observed in earlier reports by Verhoeven et al. (1996); Öquist \& Huner (1991), who reported a fast recovery of $F_{\mathrm{v}} / F_{\mathrm{m}}$ within only $48 \mathrm{~h}$. This recovery was accompanied by a concomitant epoxidation of xanthophyll cycle pigments (Fig. 1e) with rapid changes within the first $24 \mathrm{~h}$, followed by a much slower second phase, which took up to 2 wk to complete. Mild frost and relatively low light intensity during the pretreatment may have contributed to the fast recovery within the first $24 \mathrm{~h}$.

The much faster recovery observed in $F_{\mathrm{v}} / F_{\mathrm{m}}$, but not in $A_{\text {sat }}$, suggests that much faster rearrangements in the thylakoid membrane system can occur compared with the changes required to restore fully competent carbon fixation and cytosolic carbon metabolism (Fig. 4). Thus under warmer temperature conditions, recovery of the light reactions is probably simply withheld by temporary limitations in the recovery of the Calvincycle components.

After warming, levels of soluble sugars decreased in needles, with starch beginning to accumulate in the chloroplast (Fig. 6), a pattern that is consistent with reports from other conifer species (Mandre et al., 2002; Repo et al., 2005). Carbohydrate levels in 15/15 and 15F/15 shoots and roots (Fig. 6b,c) also suggest remobilisation of sugars between compartments. This 
is most likely to provide the energy required for the early increased metabolic demand for energy with the Calvin cycle and cytosolic carbon metabolism still impaired. Carbohydrate pools in shoots represent a considerable source of utilizable energy during the onset of physiological activity in spring, as indicated by the significant decrease in concentration in the $15 / 15$ seedlings compared with the low soil temperature and winter-acclimated seedlings.

\section{Low soil temperatures affect spring recovery of the photosynthetic processes}

Low soil temperatures strongly modified the processes described above. While $F_{\mathrm{v}} / F_{\mathrm{m}}$ in $15 /+1$ and $15-2$ seedlings was fully restored after $18 \mathrm{~d}$ under spring temperature conditions (Fig. 1a), the photochemical efficiency of PSII in the light $\left(\Delta F / F_{\mathrm{m}}{ }^{\prime}\right)$ was considerably lower in seedlings from the $15 /+1$ and $15 /-2$ treatments than in seedlings from $15 / 15$ or $15 \mathrm{~F} /$ 15 treatments (Fig. 1a,b). Soil temperature also had a significant effect on the water potential of needles, with $15 /+1$ and $15 /-2$ seedlings having considerably lower values than $15 / 15$ or $15 \mathrm{~F} /$ 15 plants. This pattern probably reflects initially facilitated needle transpiration under warm spring air temperature conditions, at the same time with water uptake from the soil being limited, and with water reserves from roots and shoots also presumably being small for $15 /+1$ and $15 /-2$ seedlings. Nevertheless, the water status of the needles, reflected by needle water potential in $15 /+1$ and $15 /-2$, was not excessively low enough to account for severe drought stress in Scots pine (Eastman \& Camm, 1995; Irvine et al., 1998; Repo et al., 2005 for a classification of shoot water potential in spruce seedlings). Cold-induced synthesis of abscisic acid in the roots could, however, have acted as the well described long-distance signal mediating stomatal closure before changes in leaf water potential occurred, thereby preventing further water loss by transpiration and potential desiccation (Davies \& Zhang, 1991; Irvine et al., 1998). A stomatal limitation is also suggested by the low stomatal conductance in $15 /+1$ and $15 /-2$ seedlings. However, the lower initial slope of the $A / C_{\mathrm{i}}$ relationship in 15/ +1 and $15 /-2$ seedlings additionally suggests nonstomatal limitations of photosynthesis, as indicated by low $V c_{\max }$ values (Fig. 5b). As a result, stomatal and nonstomatal effects both impaired the ability of $\mathrm{CO}_{2}$ assimilation to act as a sink for electrons derived from the photochemical reactions for the plants exposed to low soil temperatures. This probably serving continually to suppress the recovery of electron transport between PSII and PSI (Table 2). This also provides an explanation for the increased photoprotective dissipation of excess energy via xanthophyll cycle pigments for the 15/+1 and 15/-2 seedling, as compared with 15/15 seedlings (Fig. 1e,f). Although $A_{\text {sat }}$ was much lower in seedlings from cold or frozen soil conditions, RbcL levels were the same irrespective of soil temperature or water potential, suggesting significant deactivation of Rubisco as noted above. Downregulation of photosynthesis in conifers exposed to low soil temperature is also consistent with reports for Engelmann spruce and Scots pine (DeLucia, 1986; DeLucia et al., 1991; Strand et al., 2002).

In 15/-2 seedlings, PsbS levels remained relatively low, suggesting a mechanism of nonphotochemical quenching different from flexible zeaxanthin-dependent dissipation. One such mechanism, involving increased levels of $\beta$-carotene, has recently been described for Jack pine (Busch et al., 2007).

\section{Intermittent frost reversibly affects spring recovery of photosynthesis}

In contrast to the continuous low soil temperature treatments, intermittent frost exposed seedlings to only short periods of stress. The imposed sequences of subfreezing air temperatures impaired PSII efficiency in a manner similar to $15 /-2$ seedlings (Fig. 1b), and with increased excitation pressure and limitations in electron transport from PSII to PSI, as discussed above (Table 2). Rapid cold-induced stomatal closure, as reported by Wilkinson et al. (2001) for Commelina communis, and in contrast to the low soil temperature treatments, might have been the primary cause of the rapid impairment of photosynthesis. This may have been because of the direct stomatal effect of low temperature via increased $\mathrm{Ca}^{2+}$ leading to the loss of guard cell turgor and stomatal closure (Assmann \& Shimazaki, 1999), rather than the effects of increased VPD. It is also important to consider any effects of freezing temperatures restricting the transport of water and thereby contributing further to low stomatal conductance, as has been reported earlier for conifers such as black spruce (Lamontagne et al., 2000). In addition to the direct effect of chilling and water stress during intermittent frost, there is also a role for stomatal closure through an abscisic acid root signal (see above) to prevent water loss, a long-term defence mechanism proposed by Davies et al. (2002), involved in protecting from further chilling episodes. It is very likely that this mechanism prevented the formation of extremely low water potentials in our pine needles, and severe drought stress.

Chlorophyll concentrations, as well as total carotenoids, were not affected by intermittent frost in our experiments (Table 3). Nevertheless, the pool of the xanthophyll cycle pigments increased during $4 \mathrm{~d}$ of frost, demonstrating de novo synthesis of xanthophylls. The concomitant increase in zeaxanthin (Fig. 1f) and antheraxanthin (Table 3) acts as a rapid photoprotective response to mediate increased excitation pressure resulting from limitations in $\mathrm{CO}_{2}$ assimilation during short frost events. Most importantly, effects of intermittent frost during spring were rapidly reversed, with photosynthetic capacity of the seedlings fully restored within $4 \mathrm{~d}$ of return to control conditions. Nevertheless, decreased D1 levels, compared with the 15/15 treatment, suggest a loss of functional PSII on exposure to frost. Therefore the lower rates of $\mathrm{CO}_{2}$ assimilation during recovery from exposure to frost and at the end of the experiment, compared with $15 / 15$, might have been caused by decreased rates of ATP and NADPH synthesis 
caused by less efficient photochemical energy conversion and linear electron transport. An increased capacity for flexible thermal de-excitation in $15 \mathrm{~F} / 15$ at the end of the experiment, expressed by high levels of VAZ/Chl and DEPS, is also suggested by high levels of the PsbS protein (Fig. 3b).

Another mechanism involved in the stress response of $15 \mathrm{~F} / 15$ seedlings to intermittent frost is suggested by changes in the carbohydrate composition of the needles (Fig. 6a). In particular, increased levels of soluble sugars vs starch in needles resembled the pattern observed in 15/-2 and winter plants much more than that in the fully recovered $15 / 15$ seedlings. This suggests that $15 \mathrm{~F} / 15$ plants continued to exploit the cryoprotective osmotic properties of these carbohydrates (Kontunen-Soppela et al., 2002).

Thus intermittent frost inhibits the recovery process of conifers only reversibly, demonstrating a remarkable plasticity and robustness of this process. Nevertheless, intermittent frost also decreased $\mathrm{CO}_{2}$ assimilation, being only approx. $16 \%$, for example, on day 14 during intermittent frost, and approx. $65 \%$ on day $16,2 \mathrm{~d}$ after intermittent frost, compared with seedlings that were not exposed to disturbing frost events (Fig. 4). It will be interesting to study sequences of frequent frost events to determine effects of more severe disturbance regimes as well as the response of larger trees under controlled conditions.

\section{Conclusions - low soil temperatures counteract the recovery process to a greater extent than intermittent subzero air temperatures}

Both low soil temperatures and intermittent frost decrease the rate of the photosynthetic spring recovery process in conifer seedlings but, most importantly, our data indicate that low soil temperatures counteract the recovery process to a much greater extent than mild, intermittent frost. Low soil temperatures do not limit the onset of photosynthesis in spring per se, but rather reduce the actual rate of recovery and hence delay the full recovery of photosynthetic capacity.

Under generally warmer future climatic conditions, this low soil temperature effect on the spring recovery of photosynthesis could become an important issue in natural forests. Globally, a $10 \%$ reduction in the extent of snow cover has been observed over the past $40 \mathrm{yr}$, and current climate-change models predict these trends to continue (Houghton et al., 2001). Snow-removal experiments demonstrated that snow keeps the soil warm during spring, with daily averages consistently $>0^{\circ} \mathrm{C}$, whereas snow-free soil temperatures commonly dropped below $-3^{\circ} \mathrm{C}$ during spring (Decker et al., 2003). Relating our experimental data to these observations, we conclude that in the Northern hemisphere, the likely effects of increased land surface air temperatures for an earlier onset of photosynthesis in spring can be negated, at least to some extent, by generally lower soil temperatures in areas where a decrease in snow cover is predicted.

\section{Acknowledgements}

The authors thank Agnes Fastnacht for breeding the Scots pine seedlings, Susanne Tittman, Khanyisa Brian Mantlana, Falk Hänsel, Olaf Kolle and Dirk Link for technical assistance. Dr F. Berninger and Dr L. Hendrickson provided stimulating discussion and critical reading of the manuscript. I.E. is supported by a Marie Curie fellowship of the EU (PhysConFor, contract no. MOIF-CT-2004-002476).

\section{References}

Adams WW, Demmig-Adams B. 1994. Carotenoid composition and downregulation of photosystem II in 3 conifer species during the winter. Physiologia Plantarum 92: 451-458.

Adams WW, Zarter CR, Ebbert V, Demmig-Adams B. 2004. Photoprotective strategies of overwintering evergreens. Bioscience 54: 41-49.

Assmann SM, Shimazaki KL. 1999. The multisensory guard cell, stomatal responses to blue light and abscisic acid. Plant Physiology 119: 809-816.

Bergh J, Linder S. 1999. Effects of soil warming during spring on photosynthetic recovery in boreal Norway spruce stands. Global Change Biology 5: 245-253.

Björkmann O, Demmig-Adams B. 1995. Regulation of photosynthetic light energy capture, conversion and dissipation in leaves of higher plants. In: Schulze ED, Caldwell MM, eds. Ecophysiology of photosynthesis. Berlin: Springer-Verlag, 17-47.

Busch F, Hüner NPA, Ensminger I. 2007. Increased air temperature during simulated autumn conditions does not increase photosynthetic carbon gain but affects the dissipation of excess energy in seedlings of the evergreen conifer Jack Pine. Plant Physiology 143: 1242-1251.

Davies WJ, Zhang JH. 1991. Root signals and the regulation of growth and development of plants in drying soil. Annual Review of Plant Physiology and Plant Molecular Biology 42: 55-76.

Davies WJ, Wilkinson S, Loveys B. 2002. Stomatal control by chemical signalling and the exploitation of this mechanism to increase water use efficiency in agriculture. New Phytologist 153: 449-460.

Decker KLM, Wang D, Waite C, Scherbatskoy T. 2003. Snow removal and ambient air temperature effects on forest soil temperatures in Northern Vermont. Soil Science Society of America Journal 67: 1234-1242.

DeLucia EH. 1986. Effect of low root temperature on net photosynthesis, stomatal conductance and carbohydrate concentration in Engelmann spruce (Picea engelmannii Parry ex Engelm.) seedlings. Tree Physiology 2: 143-154.

DeLucia EH, Day TA, Öquist G. 1991. The potential for photoinhibition of Pinus sylvestris L. seedlings exposed to high light and low soil temperature. Journal of Experimental Botany 42: 611-617.

Demmig-Adams B, Adams WW. 2006. Photoprotection in an ecological context: the remarkable complexity of thermal energy dissipation. New Phytologist 172: 11-21.

Demmig-Adams B, Adams WW, Barker DH, Logan BA, Bowling DR, Verhoeven AS. 1996. Using chlorophyll fluorescence to assess the fraction of absorbed light allocated to thermal dissipation of excess excitation. Physiologia Plantarum 98: 253-264.

Eastman PAK, Camm EL. 1995. Regulation of photosynthesis in interior spruce during water stress - changes in gas exchange and chlorophyll fluorescence. Tree Physiology 15: 229-235.

Ebbert V, Adams WW, Mattoo AK, Sokolenko A, Demmig-Adams B. 2005. Upregulation of a photosystem II core protein phosphatase inhibitor and sustained D1 phosphorylation in zeaxanthin-retaining, photoinhibited needles of overwintering Douglas fir. Plant, Cell హ Environment 28: 232-240.

Ensminger I, Busch F, Huner NPA. 2006. Photostasis and cold acclimation: 
sensing low temperature through photosynthesis. Physiologia Plantarum 126: $28-44$.

Ensminger I, Xyländer M, Hagen C, Braune W. 2001. Strategies providing success in a variable habitat. III. Dynamic control of photosynthesis in Cladophora glomerata. Plant, Cell \& Environment 24: 769-779.

Ensminger I, Sveshnikov D, Campbell DA, Funk C, Jansson S, Lloyd J, Shibistova O, Öquist G. 2004. Intermittent low temperatures constrain spring recovery of photosynthesis in boreal Scots pine forests. Global Change Biology 10: 995-1008.

Farquhar GD, von Caemmerer S. 1982. Modelling of photosynthetic response to environmental conditions. In: Lange O, Nobel P, Osmond CHZ, eds. Physiological plant ecology II. Encyclopaedia of plant physiology. Berlin: Springer Verlag, 549-588.

Genty B, Briantais JM, Baker NR. 1989. The relationship between the quantum yield of photosynthetic electron transport and quenching of chlorophyll fluorescence. Biochimica et Biophysica Acta 990: 87-92.

Greer DH, Ottander C, Oquist G. 1991. Photoinhibition and recovery of photosynthesis in intact barley leaves at 5 and $20^{\circ} \mathrm{C}$. Physiologia Plantarum 81: 203-210.

Hansen J, Beck E. 1994. Seasonal changes in the utilization and turnover of assimilation products in 8-year-old Scots pine (Pinus sylvestris L.) trees. Trees - Structure and Function 8: 172-182.

Horton P, Ruban AV, Walters RG. 1996. Regulation of light harvesting in green plants. Annual Review of Plant Physiology and Plant Molecular Biology 47: 655-684.

Houghton JT, Ding Y, Griggs DJ, Noguer M, van der Linden PJ, Xiaosu D. 2001. Climate Change 2001: The scientific basis. Contribution of Working Group I: the Third Assessment Report of the Intergovernmental Panel on Climate Change (IPCC). Cambridge, UK: Cambridge University Press.

Huner NPA, Öquist G, Sarhan F. 1998. Energy balance and acclimation to light and cold. Trends in Plant Science 3: 224-230.

Ingestad T. 1979. Mineral nutrient requirements of Pinus silvestris and Picea abies seedlings. Physiologia Plantarum 45: 373-380.

Irvine J, Perks MP, Magnani F, Grace J. 1998. The response of Pinus sylvestris to drought: stomatal control of transpiration and hydraulic conductance. Tree Physiology 18: 393-402.

Jarvis P, Linder S. 2000. Botany - constraints to growth of boreal forests. Nature 405: 904-905.

Jermyn MA. 1975. Increasing the sensitivity of the anthrone method for carbohydrates. Analytical Biochemistry 68: 332-335.

Karpinski S, Karpinska B, Wingsle G, Hällgren JE. 1994. Molecular responses to photooxidative stress in Pinus sylvestris. 1. Differential expression of nuclear and plastid genes in relation to recovery from winter stress. Physiologia Plantarum 90: 358-366.

Kato MC, Hikosaka K, Hirotsu N, Makino A, Hirose T. 2003. The excess light energy that is neither utilized in photosynthesis nor dissipated by photoprotective mechanisms determines the rate of photoinactivation in photosystem II. Plant and Cell Physiology 44: 318-325.

Kontunen-Soppela S, Lankila J, Lahdesmaki P, Laine K. 2002. Response of protein and carbohydrate metabolism of Scots pine seedlings to low temperature. Journal of Plant Physiology 159: 175-180.

Kornyeyev D, Holaday S, Logan B. 2003. Predicting the extent of photosystem II photoinactivation using chlorophyll a fluorescence parameters measured during illumination. Plant and Cell Physiology 44: $1064-1070$

Lamontagne M, Bigras FJ, Margolis HA. 2000. Chlorophyll fluorescence and $\mathrm{CO}_{2}$ assimilation of black spruce seedlings following frost in different temperature and light conditions. Tree Physiology 20: 249-255.

Leinonen I, Repo T, Hänninen H. 1997. Changing environmental effects on frost hardiness of Scots pine during dehardening. Annals of Botany 79: $133-138$.

Li XP, Gilmore AM, Caffarri S, Bassi R, Golan T, Kramer D, Niyogi KK. 2004. Regulation of photosynthetic light harvesting involves intrathylakoid lumen $\mathrm{pH}$ sensing by the PsbS protein. Journal of Biological Chemistry 279: 22866-22874.
Lloyd J, Howie H. 1989. Response of Orchard Washington Navel Orange, Citrus sinensis (L.) Osbeck, to saline irrigation water. 1. Canopy characteristics and seasonal patterns in leaf osmotic potential, carbohydrates and ion concentrations. Australian Journal of Agricultural Research 40: 359-369.

Lopushinsky W, Kaufmann MR. 1984. Effects of cold soil on water relations and spring growth of Douglas-fir seedlings. Forest Science 30: 628-634.

Lundmark T, Hällgren J, Hedén J. 1988. Recovery from winter depression of photosynthesis in pine and spruce. Trees-Structure and Function 2: $110-114$.

Mandre M, Tullus H, Kloseiko J. 2002. Partitioning of carbohydrates and biomass of needles in Scots pine canopy. Zeitschrift Fur Naturforschung C-A Journal of Biosciences 57: 296-302.

Niyogi KK. 1999. Photoprotection revisited: genetic and molecular approaches. Annual Review of Plant Physiology and Plant Molecular Biology 50: 333-359.

Ögren E. 1997. Relationship between temperature, respiratory loss of sugar and premature dehardening in dormant Scots pine seedlings. Tree Physiology 17: 47-51.

Öquist G, Huner NPA. 1991. Effects of cold acclimation on the susceptibility of photosynthesis to photoinhibition in Scots pine and in winter and spring cereals: a fluorescence analysis. Functional Ecology 5: 91-100.

Öquist G, Huner NPA. 2003. Photosynthesis of overwintering evergreen plants. Annual Review of Plant Biology 54: 329-355.

Öquist G, Gardeström P, Huner NPA. 2001. Metabolic changes during cold acclimation and subsequent freezing and thawing. In: Bigras FJ, Colombo SJ, eds. Conifer cold hardiness. Dordrecht, the Netherlands: Kluwer Academic, 137-163.

Ottander C, Hundal T, Andersson B, Huner NPA, Öquist G. 1993. Photosystem II reaction centres stay intact during low temperature photoinhibition. Photosynthesis Research 35: 191-200.

Ottander C, Campbell D, Öquist G. 1995. Seasonal changes in photosystem II organization and pigment somposition in Pinus sylvestris. Planta 197: 176-183.

Pelkonen P, Hari P. 1980. The dependence of the springtime recovery of $\mathrm{CO}_{2}$ uptake in Scots pine on temperature and internal factors. Flora 169: 398-404.

Repo T, Kalliokoski T, Domisch T, Lehto T, Mannerkoski H, Sutinen S, Finér L. 2005. Effects of timing of soil frost thawing on Scots pine. Tree Physiology 25: 1053-1062.

Rose R, Rose CL, Omi SK, Forry KR, Durall DM, Bigg WL. 1991. Starch determination by perchloric acid vs. enzymes - evaluating the accuracy and precision of 6 colorimetric methods. Journal of Agricultural and Food Chemistry 39: 2-11.

Scholander PF, Hemmingsen EA, Hammel HT, Bradstreet EDP. 1964. Hydrostatic pressure and osmotic potential in leaves of mangroves and some other plants. Proceedings of the National Academy of Sciences, USA 52: $119-125$.

Sevanto S, Suni T, Pumpanen J, Grönholm T, Kolari P, Nikinmaa E, Hari P, Vesala T. 2006. Wintertime photosynthesis and water uptake in a boreal forest. Tree Physiology 26: 749-757.

Slot M, Wirth C, Schumacher J, Mohren GMJ, Shibistova O, Lloyd J, Ensminger I. 2005. Regeneration patterns in boreal Scots pine glades linked to cold-induced photoihibition. Tree Physiology 25: 1139-1150.

Strand M, Lundmark T, Soderbergh I, Mellander PE. 2002. Impacts of seasonal air and soil temperatures on photosynthesis in Scots pine trees. Tree Physiology 22: 839-847.

Stroch M, Spunda V, Kurasova I. 2004. Non-radiative dissipation of absorbed excitation energy within photosynthetic apparatus of higher plants. Photosynthetica 42: 323-337.

Suni T, Berninger F, Vesala $T$ et al. 2003. Air temperature triggers the recovery of evergreen boreal forest photosynthesis in spring. Global Change Biology 9: 1410-1426.

Sveshnikov D, Ensminger I, Ivanov AG, Campbell D, Lloyd J, Funk C, 
Huner NPA, Oquist G. 2006. Excitation energy partitioning and quenching during cold acclimation in Scots pine. Tree Physiology 26: 325-336.

Verhoeven AS, Adams WW, Demmig-Adams B. 1996. Close relationship between the state of the xanthophyll cycle pigments and photosystem II efficiency during recovery from winter stress. Physiologia Plantarum 96 : 567-576.

Vogg G, Heim R, Hansen J, Schäfer C, Beck E. 1998. Frost hardening and photosynthetic performance of Scots pine (Pinus sylvestris L.) needles. I. Seasonal changes in the photosynthetic apparatus and its function. Planta 204: 193-200.

Wang YF, Zwiazek JJ. 1999. Spring changes in water relations, gas exchange, and carbohydrates of white spruce (Picea glauca) seedlings. Canadian Journal of Forest Research - Revue Canadienne de Recherche Forestiere 29: 332-338.

Warren CR, Adams MA. 2004. Evergreen trees do not maximize instantaneous photosynthesis. Trends in Plant Science 9: 270-274.

Wilkinson S, Clephan AL, Davies WJ. 2001. Rapid low temperatureinduced stomatal closure occurs in cold-tolerant Commelina communis leaves but not in cold-sensitive tobacco leaves, via a mechanism that involves apoplastic calcium but not abscisic acid. Plant Physiology 126: $1566-1578$.

Zarter CR, Demmig-Adams B, Ebbert V, Adamska I, Adams WW. 2006. Photosynthetic capacity and light harvesting efficiency during the winter-to-spring transition in subalpine conifers. New Phytologist 172: 283-292.

\section{Supplementary Material}

The following supplementary material is available for this article online:

Text S1 Fitting of mixed model segmented regressions

Table S1 Model fit to equation A1 in supplementary text $S 1$

This material is available as part of the online article from: http://www.blackwell-synergy.com/doi/abs/10.1111/ j.1469-8137.2007.02273.x

(This link will take you to the article abstract).

Please note: Blackwell Publishing are not responsible for the content or functionality of any supplementary materials supplied by the authors. Any queries (other than missing material) should be directed to the journal at New Phytologist Central Office.

\section{About New Phytologist}

- New Phytologist is owned by a non-profit-making charitable trust dedicated to the promotion of plant science, facilitating projects from symposia to open access for our Tansley reviews. Complete information is available at www.newphytologist.org.

- Regular papers, Letters, Research reviews, Rapid reports and both Modelling/Theory and Methods papers are encouraged. We are committed to rapid processing, from online submission through to publication 'as-ready' via OnlineEarly - our average submission to decision time is just 28 days. Online-only colour is free, and essential print colour costs will be met if necessary. We also provide 25 offprints as well as a PDF for each article.

- For online summaries and ToC alerts, go to the website and click on 'Journal online'. You can take out a personal subscription to the journal for a fraction of the institutional price. Rates start at $£ 135$ in Europe/\$251 in the USA \& Canada for the online edition (click on 'Subscribe' at the website).

- If you have any questions, do get in touch with Central Office (newphytol@lancaster.ac.uk; tel +44 1524 594691) or, for a local contact in North America, the US Office (newphytol@ornl.gov; tel +1 865576 5261). 